\title{
A COMPARATIVE STUDY OF THE INFLUENCE OF HEAVY METALS ON SOIL AND CROPS GROWING WITHIN QUARRY ENVIRONMENT AT AKAMKPA, CROSS RIVER STATE, NIGERIA
}

\author{
F. E. EKPO, E. C. NZEGBLUE AND M. E. ASUQUO \\ (Received 14, July 2011; Revision Accepted 18, October 2011)
}

\begin{abstract}
A comparative study of the influence of heavy metals on soils and crops grown within quarry environment at Akamkpa, Cross River State was conducted in 2009 year. The study area was delineated into3 zones P1, P11, P111 based on the intensity of exposure to tailings, wind speed, wind direction and distance from the quarry. The selected sample distances were $(0 \mathrm{~km}, 1 \mathrm{~km}$ and $3 \mathrm{~km}$ as control). Soil sample with the depth of $(0-15 \mathrm{~cm})$, cassava leaves and, fluted pumpkin leaves were collected separately from each of the sampling area and analyzed for chemical characteristics. The concentration of heavy metals $\mathrm{Pb}, \mathrm{Cr}, \mathrm{Ni}, \mathrm{Cd}, \mathrm{Mn}, \mathrm{Fe}$ and $\mathrm{Cu}$ in the leaves samples of fluted pumpkin and cassava in sample position $(\mathrm{P} 1)$ were $(25.26 \pm 0.58,15.54 \pm 0.75,14.28 \pm 1.23,18.05 \pm 0.20,42.25 \pm 0.10$, $87.22 \pm 0.40$ and $28.14 \pm 0.71) \mathrm{mg} / \mathrm{kg}$ for fluted pumpkin and $(23.41 \pm 0.50,11.25 \pm 0.11,10.78 \pm 0.23,12.25 \pm 0.60$, $38.25 \pm 0.05,75.28 \pm 0.40$ and $26.51 \pm 0.15) \mathrm{mg} / \mathrm{kg}$ for cassava leaves respectively. The values of these heavy metals $\mathrm{Pb}, \mathrm{Cr}, \mathrm{Ni}, \mathrm{Cd}, \mathrm{Mn}, \mathrm{Fe}$ and $\mathrm{Cu}$ of soils in zone $(\mathrm{P} 1)$ were $(12.26 \pm 0.86, \quad 5.75 \pm 0.50,3.25 \pm 1.84$, $8.25 \pm 1.24,14.29 \pm 0.25,125.0 .85 \pm 0.05$ and $5.67 \pm 0,98) \mathrm{mg} / \mathrm{kg}$ respectively. The values of heavy metals in plant species were significant $(P<0.05)$ higher than values of the soils in sample position. Similar trend was recorded in zones $\mathrm{P} 11$ and P111. The high concentrations of trace metals recorded in the leaves of the plant species may be due to bioaccumulation and biomagnifications of those metals in plant. The decrease in concentration of these metals in the soil may be as a result of losses due to leaching, harvest of agricultural products, volatilization and soil $\mathrm{pH}$.. The correlation between heavy metals in the soil and the relationship with the soil factors showed that some metals correlate significantly and positively with other metals while some do not. It is concluded that quarry activities in Old Netim in Akamkpa Local Government Area of Cross River State has a significant impact on the level of heavy metals on crops around the area. This is a matter of great concern in view of the environmental and health implication, since man and livestock depend on these plant species for food.
\end{abstract}

KEY WORDS: Biomagnification, heavy metals, soils, economic crops.

\section{INTRODUCTION}

Quarrying is a major land used activity in Akamkpa Local Government Area of Cross River State, Nigeria. Due to the availability of mineral deposits in commercial quantity in the area, the mining activity provides large tones of chippings of various sizes as well as accompanying toxic waste affect both environment and human.

The social and environmental disturbances as a result of mining and mineral processing activities include destruction of wildlife and biodiversity, loss of fertile soil, pollution of drinking water and air, degradation of farm land, impairment of human health, forced pollution migration, destruction or reduction of agricultural and related activities and damage to aquatic ecosystems (Adepoju, 2002). The effect of mining is manifest in air, land, crops and water.
Tailings generated from mining operations and weathering of rocks is important source of heavy metals introduced into the environment (Kakulu, 2003; Nriagu, 1990). Inputs of heavy metals into the soils have gradually increased over the past decades as a consequence of agricultural practices (e.g. the use of fertilizers and pesticides), disposal of sewage sludge, and mining operations (Adriano, 1999; Berrow, 1986). Although some heavy metals are essential in plants nutrition, plants growing in an environment of heavy metals pose serious risk to human health when such plant based food stuffs are consumed (Vousta et al., 1996). Unlike energy which tend ton deplete and becomes more dispersed at each step in the trophic level, heavy metals become more concentrated with each trophic level in the food chain "bioaccumulation and biomagnifications" (Egunjobi and Nkwoko, 2002).

F. E. Ekpo, Akwa Ibom State University, Obio Campus, Oruk Anam Local Government Area, Nigeria

E C. Nzegblue, Micheal Okpara University of Agriculture, Umudike, Abia State, Nigeria

M. E. Asuquo, Micheal Okpara University of Agriculture, Umudike, Abia State, Nigeria 
The concentration of these chemicals become enhanced with progression along the trophic levels in the ecosystem rather than dissipate, a process referred to bioaccumulation (Dara, 1993). The concentration of heavy metals and other minerals in the soil are decreased due to harvests of agricultural crops, losses by leaching and volatilization (Jones, 1999). Therefore, the concentration of heavy metals in crops increases because of bioaccumulation and biomagnifications of these metals in plants. Bioaccumulation is expressed as the ratio of concentration of the chemical in the organism to that in the medium. Unfortunately, extensive research work aimed at understanding the correlation of heavy metals between the soils and plants within the quarry site and the possible effects in the food chain have no yet been done, also the important regulatory policies to minimize the environmental health hazards are not yet in place. This research was carried out to assess the relationship of heavy metals in the soils and plants within the quarry site, since the area is an agricultural zone.

\section{MATERIALS AND METHODS}

\section{Description of the study area}

The study area is at Old Netim in Akamkpa Local Government Area of Cross River State, Nigeria. It is located in the southern part of Cross River State, and lies between latitude $06^{\circ} \mathrm{C}-50 \mathrm{~N}$ and longitude $07^{\circ}-30 \mathrm{~S}$. it has a climate that can be differentiated into two seasons. The wet (rainy) season begins in March and end November, having an average annual rainfall varying between $1500 \mathrm{~mm}$ to $3000 \mathrm{~mm}$. the peak of the rainfall is June/July and in September, with a break in rains in August. The dry season last for four months, which begins in November, and end February. Humidity is high and often above $60 \%$ minimum and maximum average temperature is between $25^{\circ} \mathrm{C}$ and $36^{\circ} \mathrm{C}$ respectively (NIMET, 2008).

Old Netim village in Akamkpa Local Government Area of Cross River State is situated within the lowland rainforest zone of Nigeria. The soil type can be regarded as an acidic soil. The vegetation comprises of trees that are scattered as well as clustered oil palms. The result of large scale exploitation being carried out in the area has destroyed its original vegetation. The population of the people in this area is about 95000(NPC, 2007) and their main occupation is farming . the farmlands are owned by individuals according to the traditional land tenure system and the major crops grown include cassava, yam, maize, fluted pumpkin, cocoyam etc.

Quarrying activities started in 1982, presently there are three (3) companies that are carrying out quarrying in the area; namely: Cross Rock company, PRODECO (Property development company) and HITECH company.

\section{Method of study}

The samples were randomly collected at three different positions within the rock mining site. Prior to the collections of samples, three (3) coated pans were kept for 3 days in different distances to delineate the position where the samples were to be collected, in order to ascertain the amount of dust produced during the quarrying process that could settle in the pans. The first zone (P1) was $0 \mathrm{~km}$ within the quarry site, the second zone (P11) was $1 \mathrm{~km}$ away from the quarry site and the third zone (P111) used as control was $3 \mathrm{~km}$ away from the quarry site. At each of the three sampling positions, two different plant species of economic value were identified to be occurring commonly in the 3 sampling positions and were therefore selected as screening materials of heavy metals. Leaves were collected from 2 plant species (Table 1) in the 3 sampling locations, the leaf samples were collected using secautuer. The leaf samples were oven dried at $60^{\circ} \mathrm{C}$ to a constant weight, milled, sieved and digested.

At each of the sampling positions $(0 \mathrm{~km}, 1 \mathrm{~km}$ and $3 \mathrm{~km}$ ) a $50 \mathrm{~g}$ soil samples were collected randomly from a depth of $0-15 \mathrm{~cm}$ using soil auger. The soil samples were collected on 4 replicate points at each sampling location. The soil samples were air dried, screened, sieved and digested. The different types of samples were digested and extracted using $0.1 \%$ perchloric acid. The extracts were analyzed for $\mathrm{Ni}, \mathrm{Cd}$, $\mathrm{Cr}, \mathrm{Pb}, \mathrm{Cu}$ and $\mathrm{Fe}$ using the Atomic Absorption Spectrophotometer (Unicam 919 model) at the Aluminum Smelter Company Laboratory, Ikot Abasi Akwa Ibom State, Nigeria (ALSCON).

\section{Statistical Analysis}

Data collected were analyzed using the Analysis of Variance (ANOVA) procedure (Steel and Torrie, 1980). Experimental means were compared using the least significant different (LSD) $\mathrm{P}<0.05$.

\section{RESULTS AND DISCUSSION}

The concentrations of heavy metals $\mathrm{Fe}, \mathrm{Pb}, \mathrm{Cr}$, and $\mathrm{Ni}$ in the three (3) sampling positions P1, P11 and P111 are shown in (Table 1). The highest concentrations of all the heavy metals analyzed from the samples were recorded in the sampling position $(0 \mathrm{Km})$ which is the immediate vicinity of the quarry. Plant species samples had a high value of heavy metals than the soil in all the sampling positions, except in the case of $\mathrm{Fe}$ that had the highest concentration than the plant species. The high value of $\mathrm{Fe}$ may be due to the present of $\mathrm{Fe}$ in the rock (Berrow, 1986). The values of the concentrations of $\mathrm{Cd}, \mathrm{Zn}$, and $\mathrm{Cu}$ (Table 2) were significantly $(\mathrm{P}<0.5)$ higher in plant species than in soil during the study period. It is observed that concentration of these heavy metals decreased with increase in the distance from quarry. The higher concentrations of heavy metals recorded in sampling positions within the quarry site confirms the relationship between metals concentration and distance from the quarry. The uptake of heavy metals in plants and the translocation were influenced by differences in the mobility of the metals in the plants. $\mathrm{Fe}$ and $\mathrm{Zn}$ had the highest values of $78.64 \mathrm{mg} / \mathrm{kg}$ and $27.28 \mathrm{mg} / \mathrm{kg}$ in pumpkin leaves and $79.24 \mathrm{mg} / \mathrm{kg}$ and $25.64 \mathrm{mg} / \mathrm{kg}$ in cassava leaves respectively. The result is in line with the work of (Kabata- Pendias, 1992) who reported that $\mathrm{Fe}$ and $\mathrm{Zn}$ are essential trace elements, in which plants and animals need in large quantity for their metabolic activities. The concentrations of $\mathrm{Fe}$ and $\mathrm{Pb}$ in cassava leaves tend to be higher in sampled position two (P11) than the in the leaves of pumpkin. 
In all the plants examined, higher concentrations of heavy metals $(\mathrm{Pb}, \mathrm{Cr}, \mathrm{Ni}, \mathrm{Cd}$, and $\mathrm{Zn})$ recorded in sampling positions $\mathrm{P} 1, \mathrm{P} 11$, and $\mathrm{p} 111$ were higher values obtained from the soils. Marschner, (1998); Catald et al, (2004); Ponyat and McDonnell, (1991) reported that concentration of heavy metals contained in plants may be higher than that of the soil on which they are growing due to the ability of the roots of plant to absorb the elements from the soil and these elements will be stored and accumulate in the plant tissues, process known as bioaccumulation and biomagnification. In the other hand the decrease in the concentration of heavy metals in the soil could be due to harvest of agricultural crops, leaching and volatilization (Jones, 1999). On all the soils examined, a decrease of heavy metals concentration was observed as the distance from the quarry increased, but their concentration in the plant top was consistent. The reversed trend in plant may be linked to the ability of roots to absorb the heavy metals in their rhizosphere. Ruhling, (1968) reported that the dominant factor influencing the rhizosphere is the form in which heavy metals are absorbed. This is attributed to their varying physiological differences and relative selectivity on the uptake of these metals. Dara (1993) reported that the availability of heavy metals for plant absorption depended on the ionic form in which the metals occurred in the soil and their relationship with the soil factors.

Therefore, the concentration of heavy metals recorded in this study was more than the recommended level of $0.05 \mathrm{Kg}$ for soils and vegetable species (FEPA, 1991). The influence of heavy metals on soil and crops growing within the quarry environment at Akamkpa Local Government Area of Cross River State, Nigeria is a matter of great concern in view of the environmental and health implication to the people. This raises a lot of environmental concern because both man and livestock depend on these plant species for food. Consequently, they are inadvertently exposed to gradual accumulation of these heavy metals. In a similar study, high $\mathrm{Pb}$ level was found in the blood sample of cattle reared near a smelter plant (Neuman and Dollhopt, 1992).

Table 4 shows the correlation coefficient matrix showing the association among concentrations of heavy metals in the soil and their relationships with soil factors. Fe correlate very significantly and positively with $\mathrm{Zn}(0.585)$, $\mathrm{Ni}(0.667), \mathrm{Cr}(0.618)$ and $\mathrm{Cd}(0.517)$ but did not correlate with $\mathrm{Cu}$. Copper correlated significantly and positively with $\mathrm{Zn}(0.575)$ and $\mathrm{Cd}(0.567)$ but did not show any relationship with $\mathrm{Fe}$, and $\mathrm{Cr}$. $\mathrm{Zn}$ has a strong relationship with all metals. Other researchers have found $\mathrm{Zn}$ to be highly associated with all metals (Kuo et al, 1990; Rapin et al,. 1982).

Examination of the relationships existing among the heavy metals in the soil and soil factors showed that organic matter and effective cation exchange capacity had no relationship with trace metals. The clay content correlated significantly and positively $\mathrm{Cu}(0.523)$ and $\mathrm{Zn}$ (0.453). Sand correlated negatively with $\mathrm{Fe}(-0.165)$ and $\mathrm{Cu}(-0.226)$ where as silt has no relationship with heavy metals. Similar observations were made by (Sedberry et al., 1976, and Ano, 1994), they reported that the factors which largely control the concentrations of these elements in the soil were soil factors and clay minerals.

Table 1: Concentration $(\mathrm{mg} / \mathrm{kg})$ of heavy metals in plant leaves and soils at different sampling Distance from the quarry

\begin{tabular}{|c|c|c|c|c|c|c|c|c|c|}
\hline & \multicolumn{3}{|c|}{ Sample position $1(0 \mathrm{~km})$} & \multicolumn{3}{|c|}{ Sample position $11(1 \mathrm{~km})$} & \multicolumn{3}{|c|}{ Sample position $111(3 \mathrm{~km})$} \\
\hline & $\begin{array}{l}\text { Soil } \\
(0- \\
15 \mathrm{~cm})\end{array}$ & $\begin{array}{l}\text { Pumpkin } \\
\text { Leaves }\end{array}$ & $\begin{array}{l}\text { Cassava } \\
\text { Leaves }\end{array}$ & $\begin{array}{l}\text { Soil } \\
(0-15 \mathrm{~cm})\end{array}$ & $\begin{array}{l}\text { Pumpkin } \\
\text { Leaves }\end{array}$ & $\begin{array}{l}\text { Cassav } \\
\text { a } \\
\text { Leaves }\end{array}$ & $\begin{array}{l}\text { Soil } \\
(0-15 \mathrm{~cm})\end{array}$ & $\begin{array}{l}\text { Pumpkin } \\
\text { Leaves }\end{array}$ & $\begin{array}{l}\text { Cassava } \\
\text { Leaves }\end{array}$ \\
\hline Iron & 125.05 & 87.22 & 75.28 & 85.28 & 76.28 & 83.17 & 35.38 & 32.68 & 28.27 \\
\hline Lead & 12.26 & 25.58 & 23.41 & 5.36 & 15.05 & 17.14 & 2.56 & 11.48 & 9.15 \\
\hline Chromium & 5.75 & 15.54 & 11.25 & 2.28 & 7.85 & 6.05 & 0.94 & 3.50 & 2.14 \\
\hline Nickel & 3.25 & 14.28 & 10.78 & 2.98 & 11.84 & 8.25 & 1.56 & 6.35 & 5.28 \\
\hline Cadmium & 8.25 & 18.05 & 16.25 & 3.28 & 14.28 & 10.05 & 0.98 & 8.57 & 6.28 \\
\hline Zinc & 14.75 & 42.25 & 38.29 & 9.92 & 28.40 & 27.15 & 4.14 & 12.82 & 11.38 \\
\hline Copper & 7.38 & 20.15 & 16.78 & 4.48 & 19.28 & 14.28 & 1.26 & 4.37 & 5.38 \\
\hline
\end{tabular}

Table 2: Mean concentration $(\mathrm{mg} / \mathrm{kg})$ of heavy metal content in soil and vegetables in the study area

\begin{tabular}{|l|l|l|l|l|}
\hline Elements & Soil $(0-15 \mathrm{~cm})$ & Pumpkin leaves & Cassava leaves & LSD $(0.05)$ \\
\hline Iron $(\mathrm{Fe})(\mathrm{mg} / \mathrm{kg})$ & 81.90 & 78.64 & 79.24 & 0.65 \\
\hline Lead $(\mathrm{Pb})(\mathrm{mg} / \mathrm{kg})$ & 6.72 & 15.12 & 16.67 & 1.53 \\
\hline Chromium $(\mathrm{Cr})$ & 2.99 & 8.18 & 6.24 & 1.12 \\
\hline Nickel $(\mathrm{Ni})$ & 2.65 & 10.24 & 7.18 & 1.20 \\
\hline Cadmium $(\mathrm{Cd})$ & 4.38 & 13.36 & 8.14 & 1.05 \\
\hline Zinc $(\mathrm{Zn})$ & 8.93 & 27.28 & 25.64 & 2.47 \\
\hline Copper $(\mathrm{Cu})$ & 4.24 & 14.72 & 12.05 & 2.04 \\
\hline
\end{tabular}




\section{CONCLUSION}

The higher concentration of these trace elements on the planted vegetables reported in this study, calls for scientific awareness and requires further study as to evaluate the optimum concentration needed for human health. Until that is done, planting of vegetables for human and animal use should be suspended for now based on the toxic levels, which could be hazardous to health.

\section{REFERENCE}

Adepoju, S. O., 2002. Effect of alluvial gold extraction on water soil acidity and organic matter. Igun, Nigeria J. Engineering 1:30-33

Adriano, D. C., 1999. Trace elements in the Terrestrial Environment, Springer Verlag. New York.

Ano, A. O., 1994. Trace metals studies on soils of the Nigerian Coastal plain sands I. Status of $\mathrm{Cu}, \mathrm{Zn}$, $\mathrm{Pb}$, and Mn. J. Soil and Crops 4(1): 1-5

Berrow, M. I., 1986. An overview of soil contamination problems, in Lester, Perry, Sterrit (Eds). Proceedings of the international conference on chemicals in the Environment, Selper, London, 543-552

Catald, M. H.; Ponce, S. R. and Grifford, C. H., 2004. Evaluating base line data for trace elements, $\mathrm{pH}$, organic matter content and Bulk density in Agricultural soils in Nigeria. J. water, air and soil pollut. 86: 13-280.

Dara, S. S., 1993. A text book of Environmental Chemistry and pollution control. S. Chand and Company, Ram Nagar, New Delhi.155-175.

Egunjobi, P. and Nwoko, J. T., 2002. Differential accumulation of lead on selected edible vegetables associated with roadside gardening in Nigeria. Trop. J. Applied Sc. 2 (1): 29-35

FEPA, 1991. National Guidelines and Standard for Industrial Effluents, Gaseous Emission and Hazardous Waste Management in Nigeria 59-66

Jones, K. C., 1999. Contaminant trends in soil and crops Environmental pollution. 69: 311-325

Kabata-Pendias, A. H., 1992. Trace metals in soils and plants, $2^{\text {nd }}(\mathrm{Ed})$. CRC Press, Boca Raton.
Kakulu, S. E., 2003. Trace metals in soils and vegetation from some mining Area in Nigeria. Global J. of Pure and Applied Sc.9 (3): 331-337

Kuo, S. P.; Heilman, P. E. and Baker, A. S., 1990. Distribution and forms of copper, zinc, cadmium iron, and manganese in soils near a copper smelter. J. Soil Sc.135 (2): 101-109

Marschner, I. O., 1998. The flux of $\mathrm{Cd}, \mathrm{Pb}$. In: mining polluted soils. J. water, air and soil pollut. 73: 333-339

Neuman, I. K. and Dollhopt, P. M., 1992. Lead levels in blood from cattle residing near a $\mathrm{Pb}$ smelter. J. Environ. Qulty, 21(2): 181-185

NIMET., 2008. Nigerian Climate Review Bulletin, Cross River Basin Development Authority, Calabar Station

NPC., 2007. Population census of River State. In: census 2009; National summary. National population commission (NPC), Abuja, Nigeria.

Nriagu, J. O., 1990. Historical records of metals pollution in sediments of Toronto and Hamilton Harbores. J. Great Ackes Res. 9 (3): 3655-372

Ponyat, R. V. and McDonnell, M. Y., 1991. Heavy metal accumulation of forest soil along an urban, rural gradient, in South Eastern New York. Air, Soil pollution and U. S. water. 23(56): 797-807.

Rapin, F. S.; Kuzmix, C. R.; Born, K. T. and Breji, J. S., 1982. Heavy metal contamination of spontaneous vegetation and soil around the copper smelter, Legnica Acta Soc. Bot. Pol. 62 (3): 53-57

Ruhling, A. S., 1968. An Ecological approach to the lead problem. Bot. Notiser; 121: 321-342

Sedberry, S. J.; Valenta, P. and Nurnberg, H. W., 1976. Simultaneous determination of the toxic metals $\mathrm{Cd}, \mathrm{Cu}, \mathrm{Pb}$, and $\mathrm{Zn}$. In: Soils by Differential pulse Anodic stripping voltametry. Fre. Anal. Chem. 313: 390-394.

Steel, P. G. and Torrie, J. H., 1980. Principles and procedures of statistics: A biometric approach. Second Edition, Mc-Graw Hill Book Co., New York, USA.

Vousta, D; Grimanis, A. and Samara, C., 1996. Trace elements in vegetables grown in an industrial Area in relation to soil and air particulate matter. J. Environ. Pollut. 94(3): 325-335. 